\title{
Why Should Municipalities Use Management Information Systems in Their Decision-Making Processes?
}

\author{
Cigdem Tarhan \\ Dokuz Eylül University/Management Information System, Izmir, 35160, Turkey \\ E-mail: cigdem.tarhan@deu.edu.tr \\ Can Aydın \\ Dokuz Eylül University/Management Information System, Izmir, 35160, Turkey \\ E-mail: can.aydin@deu.edu.tr
}

Received: 29 January 2019; Accepted: 17 February 2019; Published: 08 April 2019

\begin{abstract}
In recent years, rapid developing information and communication technology has been changing swiftly our insight of management perspective in our country and the World. Generally, dynamic and visionary private sector enterprises could easily adapt to these changes. From the point of information systems view, local governments just like the private sector which produce services. Local governments provide services to people living within the boundaries, but they never think or act as profit-oriented private sector. In new economy, cities are becoming more interconnected economically, culturally, and infrastructural through the parallel development of global telecommunication and transportation networks. Firstly, it has been investigated what factors affect the adoption of information technologies in Izmir Metropolitan Municipality. A survey was developed to measure the factors affecting the use of information technology in municipalities. The survey questions were prepared according to the effects of the above organizational factors. Also it was conducted with the managers of the branch manager level in Izmir Metropolitan Municipality. Finally, the results of the study were discussed and give a contribution to the literature.
\end{abstract}

Index Terms-Decision Making, Municipalities, Management Information System, Innovation.

\section{INTRODUCTION}

In recent years, rapid developing information and communication technology (ICT) has been changing swiftly our insight of management perspective in our country and the world. Generally dynamic and visionary private sector enterprises could easily adapt to these changes. Additionally, it seems that municipalities have adapted to administrative changes over time [1]. The most important element in the essence of change is "knowledge". In today's management approach;
"Information" is at the center of our lives with increasing value and today's society is also called information society [2]. For private sector businesses, information is the most asset that adds value to them and creates competition. Good management of information provides uncovering of valuable information within the organization and ensure the spread of the units needed in business. Organizations need to use information systems that effectively utilize information technology for managing information.

Information systems help organizations to produce new products and analyze problems besides being supportive to make decisions, coordinate and control. If we look at the use of information systems in terms of local governments; these organizations are just like the private sector which produces services. Local governments provide services to people living within the boundaries, but they never think or act as profit-oriented private sector [3]. In new economy, cities are becoming more interconnected economically, culturally, and infrastructural through the parallel development of global telecommunication and transportation networks.

The process of adopting information technology for effective decision-making in local governments has begun with the emergence of the e-government paradigm in the past forty years [4]. Local governments are in the process of transitioning to the e-government paradigm [5] In this process; local governments have moved from a traditional bureaucratic paradigm that adopts division and formalization principles to coordinated network buildings, external cooperation and customer service understanding. This transition process can be monitored from the institutions web pages. Institutional web pages evolve from organizational structure to informative and useroriented structure. The publication of information and services over the internet in local governments and the egovernment paradigm are causing changes within the organization [6-8]. Local governments generally think that information technology will enhance public services and organizational efficiency; for example, e-services 
offered to citizens will increase citizen satisfaction [9], [10] or that intranet use within the organization will provide citizen trust [11], which will increase operational efficiency and provide quick and correct decision [12], [13] your accountability [14]. Despite the fact that the adoption of Information Technology (IT) adoption is not considered to increase organizational success and productivity in the empirical studies, it is seen that determinants and targets should be included in the account. In Wang's study in 2014, examining the decisive factors for adapting information and communication technologies to local governments, both e-service and intranet adoption are related to staff constraints, work routines, organizational constraints and risk-taking culture [15]. Another study is mentioned that the use of information and communication technologies in local governments determines the rate of adoption of political environment, administrative structure, e-government applications [16]. In 2004, Ho and $\mathrm{Li}$ conducted that measuring the adaptation of IT use to the treasury department in Iowa. In the study, the adaptation decision was analyzed according to whether the website owner and e-government services provided. Factors affecting these two factors were the impact of independent variables such as local business and general community needs for online services, population size, development of e-government use in neighboring cities, budget constraints, budget competition with other departments, IT staff, IT budget, IT training fee paid to employees, IT the difficulties in catching development, the support for selected managers' adaptation to IT, the age of employees in the IT department in the IT department for online services [5]. The municipalities have also found that eservices and intranet use are effective in adapting IT usage.

In this study, a scale was used that influenced the adoption of information technologies developed by Wang in 2014. Using this scale, a survey was conducted by the branch managers of the decision maker level of the metropolitan municipality of Izmir. Research model of the paper was based on this survey and results' discussions.

The first part of the paper introduce the reasons of the paper and brief information about local governments. Related word, section II, is the literature part of the paper. Section III is about Research Model. In this section, survey design and survey sampling topics are discussed. $\mathrm{IV}^{\text {th }}$ section is methodology. The last section is conclusion in terms of Machine Bureaucracy, Organizational Routine, Personnel Restrictions and Risk Taking.

\section{RELATED WORKS}

Many researchers have argued that the use of IT in local governments' cause structural changes in the organization, but it is not at the same level for each institution. Organizational structures and technical infrastructure of institutions determine the extent to which this change will take place. Some local governments in the same scale provide enhanced eservices over web pages, while others use only web pages at the level of corporate information [36]. The use of intranets within the organization is also an important tool for institution employees such as e-services. The intranet is an effective and effective tool for sharing, organizing and collecting large amounts of data within the organization [7]. In local governments, the intranet network is generally used at the level of operational information systems such as document management system, fault tracking system, urban information system. One of the research questions to be answered within the scope of the study is to investigate how the systems used in the operational level within the intranet network have an effect on the decision making stage.

In literature review, there are many studies examining the organizational factors that influence the adoption of IT use in organizations [15]. Within this study, the organizational factors investigating the adoption of IT use in local governments are machine bureaucracy, work routines, personnel constraints and risk taking culture. The relationship between the factors and the use of intranets and e-services within the organization is examined and the tendency to use information technologies in the decision-making process is revealed.

In this context, the machine bureaucracy is the major bureaucracy that produces standard services. In the machine bureaucracy, a centralized management team and decision-making mechanism are overwhelming [17]. It seems that the management of cardiac insufficiency services in the United Kingdom cannot be dealt with, such as the use of machine bureaucracy, because of limited resources, and increased needs [18]. When the results of the study are examined, it has been revealed that in order to be able to perform these services better, it is necessary to have a more flexible structure that enables the related parts to work organically. Centralized structures in public institutions reduce the possibility of providing services to citizens through the use of IT within the institution [19]. For this reason, the hypothesis is accepted that the machine bureaucracy has a negative impact on the adoption of IT use during decision-making $[20,21]$.

Organizational routines are meticulous rules, methods and practices developed to deal with known situations [22]. Business processes are the whole of organizational routines. Employees can be productive and efficient when they are aware of these routines [23-25]. However, employees who are constantly applying the same business processes are resistant to using a new information technology in their business processes. Besides, Pentland and Feldman point out that organizational routine can offer great opportunities within the organization in terms of socio-technical [26]. In 2012, [27] found that the organizational routine played a negative role in the adoption of IT use in public institutions. In this study, municipalities are expected to negatively influence the use of IT by the organizational routine in the decision making phase.

The laws and regulations governing the protection of 
personnel in public institutions are seen as the biggest obstacles to organizational innovation [28]. The same fee is not paid for the same work within the scope of innovation development in public institutions and the use of IT is negatively affected due to obstacles in front of existing laws for institutional employees. The private sector employs a reward system for all kinds of innovations they make in order to motivate employees. The absence of such a structure in the public sector is also hampering IT development. The tactical and strategic progress within the institution is usually made for political reasons and does not depend on the ability of the manager to be a better decision maker. This is the legislative and political authority that allows the negative situation. For this reason, employees at the tactical level are more concerned about the use of IT for more effective decision-making. In this context, the hypothesis is suggested that staff constraints are negatively related to intranet and e-service adaptation.

In recent years, outcome-oriented approaches to citizens in the private sector have also been used in the public sector, especially in municipalities, to better serve citizens. The citizen-centered approach has become a matter of competition over time, although it has been adopted by all municipalities. This competition increases local governments' competitiveness and IT applicability to each other. This change encourages and increases the use of IT in municipalities. Administrators need to take risks for using IT solutions in municipalities. In this context, areas of risk managers in the organization greater use of IT solutions and thus allows the organization to work more efficiently [29,30]. IT solutions have the potential to create two types of risk in local governments as well as to increase efficiency within the organization. First, in-house employees are not able to adapt to the IT solutions at the expected level and thus make the current operation not work efficiently. The other risk is that information technology cannot be equally used by all segments in the services offered to citizens.

Taking the above-mentioned risks encouraging IT investment and the managers often provide increased efficiency in the institutions. In this context, the decisionmaking process within the institutions taking a risk study is expected to affect positively. In this context, the hypothesis is suggested that risk-taking is positively related to intranet and e-service adaptation.

\section{RESEARCH MODEL}

The organizational structure, culture of risk taking, personnel, organizational structure have been determined as factors affecting effective decision making processes in municipalities. The impact of all these factors on eservices and intranet adaptation will be assessed separately.

\section{A. Survey Design}

The questionnaire method has been used in this study, where the rate of adoption of information technology in the decision-making processes in municipalities. Before the questionnaire design, the literature was examined in depth. Conceptual discussions and empirical studies were found in the related literature. When these studies are examined; machine bureaucracy, organizational routine, personnel restrictions and risk taking issues were used in determining the survey questions. The opinions of many experts who were competent in their field were taken in the design of the questionnaire. Because of the intensity of the international literature, the translations used in the questionnaire have been translated into Turkish. By using the above-mentioned expressions, a scale that can be answered with equally spaced Likert type expressions in the survey design was used. The questionnaire consists of two parts. In the first chapter, four questions were asked: age, level of education, how many years you have been working, and the city you live in. In the second part of the questionnaire, there are 24 questions that are prepared according to the 5-point Likert type (1-Totally Disagree, 2-Disagree, 3-Undecided, 4-Agree, 5-Totally Agree).

\section{B. Survey Sampling}

The population of the work is 212 branch managers working in various units of the İzmir metropolitan municipality. Branch managers have been selected because they are at the first and most common level of use of information technology and decision making in municipalities. Selected participants are working-level decision makers in municipalities. Since it is not possible to reach the whole of the population, 61 branch managers were selected for the field studies, which constitute the sample of the research with easy sampling technique. The size of the sample (61 units) is supposed to represent $33 \%$ of the population (212 units). The designed questionnaire was sent to the branch offices of İzmir metropolitan municipalities via e-mail. The purpose and scope of the survey is stated on the questionnaire so that the statements in the questionnaire can be clearly understood. The demographic characteristics of the respondents are given in Table 1.

Table 1. Demographic Structure of Participants of Survey

\begin{tabular}{|c|c|c|}
\hline Education Level & Frequency & Percent (\%) \\
\hline Undergraduate & 25 & 41 \\
\hline Graduate & 28 & 45,9 \\
\hline Phd & 8 & 13,1 \\
\hline TOTAL & $\mathbf{6 1}$ & $\mathbf{1 0 0}$ \\
\hline \multicolumn{3}{|c|}{} \\
\hline Age & Frequency & Percent (\%) \\
\hline $25-30$ & 12 & 19,7 \\
\hline $31-35$ & 21 & 34,4 \\
\hline $36-39$ & 11 & 18 \\
\hline $40-45$ & 9 & 14,8 \\
\hline $45-49$ & 8 & 13,1 \\
\hline TOTAL & $\mathbf{6 1}$ & $\mathbf{1 0 0}$ \\
\hline
\end{tabular}

$19,7 \%$ of the participants are in their $20 \mathrm{~s}, 52.4 \%$ in their $30 \mathrm{~s}$ and $27.9 \%$ in their $40 \mathrm{~s}$. According to the answers, $41 \%$ of the employees are graduated, $45,9 \%$ are graduates and 13,1\% are graduates of doctorate. Age and educational level indicate that the sample exhibits a 
homogeneous distribution.

\section{Methodology}

Within the scope of the study, a survey was conducted to examine the adaptation of information technology to branch managers of İzmir Metropolitan Municipality. In order to measure the adoption of IT use in decisionmaking processes in municipalities, a two-stage analysis process was also set up in this study. (1) Reliability analysis, validity analysis and factor analysis (2) final analyzes. The results were entered into the $\mathrm{R}$ program and the reliability of the questionnaire was tested. The Cronbach's Alpha coefficient was calculated to investigate the reliability levels of the scale. Reliability is defined as the consistency of the responses of a person to a survey [31]. The reliability test of the scale is performed by calculating the average correlation area of the substances [32]. Reliability analysis is expected to indicate that the alpha coefficient is higher than 0.70 to tell whether the scale is reliable [33]. An adequate description of the contents has been provided in the direction of the reliability analyzes performed. It was deemed appropriate to use the questionnaire in the selected sample group. Six items that lowered the alpha value during the survey were excluded from the analysis. When the expected level of 0.70 was achieved, the substance extraction process was terminated from survey.

Factor analysis was applied to test the validity of the questionnaire and to test whether the factor structure of the scale meets the theoretical expectations [34]. The Kaiser-Meyer-Olkin (KMO) sample adequacy statistic was used to determine the suitability for factor analysis. The results of the statistic revealed that correlations between the items are in accordance with the factor analysis (KMO:0.690).

Table 2. Factor Analysis Result

\begin{tabular}{|c|c|c|c|c|}
\hline $\begin{array}{c}\text { Factor } \\
\text { Analysis }\end{array}$ & $\begin{array}{c}\text { Machine } \\
\text { Bureaucracy }\end{array}$ & $\begin{array}{c}\text { Organiz } \\
\text { ational } \\
\text { Routine }\end{array}$ & $\begin{array}{c}\text { Personnel } \\
\text { Restrictions }\end{array}$ & $\begin{array}{c}\text { Risk } \\
\text { Taking }\end{array}$ \\
\hline Question5 & 0.756 & & & \\
\hline Question6 & 0,508 & & & \\
\hline Question7 & 0.736 & & & \\
\hline Question8 & 0.904 & & & \\
\hline Question10 & & 0,365 & & \\
\hline Question11 & & 0,678 & & \\
\hline Question12 & & 0,656 & & \\
\hline Question13 & & 0,630 & & \\
\hline Question14 & & 0.845 & & \\
\hline Question15 & & & 0,647 & \\
\hline Question16 & & & 0,568 & \\
\hline Question17 & & & 0.549 & \\
\hline Question18 & & & & 0.527 \\
\hline Question24 & & & & 0.908 \\
\hline Question25 & & & & \\
\hline Question26 & & & & 0.552 \\
\hline
\end{tabular}

Factor loads representing the correlations between variables and factors were examined. If the factor value is more than 0, 45, the expressions above this value are taken into consideration. Factor-low items were excluded from the questionnaire by repeating factor analysis until the appropriate result was achieved. Findings of the results of factor analysis of all the items are given in Table 2. 4-dimensional factor structure was obtained in factor analysis. Four factors explain $70,445 \%$ of the total variance. According to the results obtained, the analysis reveals the factors, the total variance in the materials and the variance related to the scale. This supports the validity of your scale.

In the analysis of the data, firstly the mean and frequency methods are summarized. Following descriptive statistics, in the analysis of likert type questions in the second part of the questionnaire, machine bureaucracy, organizational routine and personnel constraints and risk taking headlines by two-way ANOVA methods. The two-way ANOVA test measures whether the branch managers differ according to machine bureaucracy, organizational routine and personnel constraints and risk taking results for the adaptation of information technology use. In order to be able to apply two-way ANOVA to the data, the data must first have normal distribution [35]. In this context, firstly shapirowilkinson normality test was performed. Test results showed that the data were distributed normally and were suitable for two-way ANOVA.

\section{FINDINGS}

\section{A. Machine Bureaucracy}

A two-way analysis of variance was conducted on the influence of four independent variables (Question5, Question6, Question7 and Question8) on the e-service adaptation (Table 3).

There was not a significance effect of Question5 on eservice adaptation at the $\mathrm{p}>.05$ level for conditions $[\mathrm{F}=0.114, \mathrm{p}<.7383]$, there was a significance effect of Question6 on e-service adaptation at the $\mathrm{p}<.05$ level for conditions $[\mathrm{F}=3.665, \mathrm{p}<.0481]$, there was a not significance effect of Question7 on e-service adaptation at the $\mathrm{p}<.05$ level for conditions $[\mathrm{F}=1.293, \mathrm{p}<.2671]$, and finally there was a significance effect of Question8 on eservice adaptation at the $\mathrm{p}<.05$ level for conditions $[\mathrm{F}=2.170, \mathrm{p}<.0683]$. The interaction effect between Question5, Question6, Question7 and Question8 under machine bureaucracy factor was not significant $\mathrm{F}=2.445$, $\mathrm{p}<0.1316$. In the results we claimed that machine bureaucracy has negative effect on e-service adaptation with determining TukeyHSD Posthoc analysis.

A two-way analysis of variance was conducted on the influence of four independent variables (Question5, Question6, Question7 and Question8) on the intranet adaptation. All effects were statistically significant at the .05 significance level.

There was a not significance effect of Question5 on intranet adaptation at the $\mathrm{p}<.05$ level for conditions $[\mathrm{F}=0.883, \mathrm{p}<.357]$, there was a significance effect of Question6 on intranet adaptation at the $\mathrm{p}<.05$ level for 
conditions $[\mathrm{F}=2.018, \mathrm{p}<.0169]$, there was a significance effect of Question7 on intranet adaptation at the $\mathrm{p}<.05$ level for conditions $[\mathrm{F}=2.862, \mathrm{p}<.0363]$, and finally there was a not significance effect of Question8 on intranet adaptation at the $\mathrm{p}<.05$ level for conditions $[\mathrm{F}=0.217$, $\mathrm{p}<.645]$. The interaction effect between Question5, Question6, Question7 and Question8 under machine bureaucracy factor was significant $\mathrm{F}=2.372$, $\mathrm{p}<0.0548$. In the results we claimed that machine bureaucracy has negative effect on intranet adaptation with determining TukeyHSD Posthoc analysis. According to these results, $\mathrm{H} 0$ hypothesis is supported

\section{B. Organizational Routine}

A two-way analysis of variance was conducted on the influence of four independent variables (Question10, Question11, Question12, Question13 and Question14) on the e-service adaptation. There was a not significance effect of Question10 on e-service adaptation at the $p<.05$ level for conditions [F=1.906, $\mathrm{p}<.1907]$, there was a significance effect of Question 11 on e-service adaptation at the $\mathrm{p}<.05$ level for conditions $[\mathrm{F}=2.790, \mathrm{p}<.02038]$, there was a significance effect of Question 12 on e-service adaptation at the $\mathrm{p}<.05$ level for conditions $[\mathrm{F}=3.053$, $\mathrm{p}<.03236]$, there was a not significance effect of Question13 on e-service adaptation at the $\mathrm{p}<.05$ level for conditions $[\mathrm{F}=1.917, \mathrm{p}<.1895]$ and finally there was a not significance effect of Question 14 on e-service adaptation at the $\mathrm{p}<.05$ level for conditions $[\mathrm{F}=1.819, \mathrm{p}<.2005]$. The interaction effect between Question10, Question11, Question12, Question13 and Question14 under organizational routine factor was not significant $\mathrm{F}=0.051$, $\mathrm{p}<0.8253$. In the results we claimed that organizational routine has negative effect on e-service adaptation with determining TukeyHSD Posthoc analysis.

A two-way analysis of variance was conducted on the influence of four independent variables (Question10, Question11, Question12, Question13 and Question14) on the intranet adaptation (Table 4).

There was a not significance effect of Question10 on intranet adaptation at the $\mathrm{p}<.05$ level for conditions $[\mathrm{F}=0.001, \mathrm{p}<.9803]$, there was a significance effect of Question11 on intranet adaptation at the $\mathrm{p}<.05$ level for conditions $[\mathrm{F}=3.013, \mathrm{p}<.05122]$, there was a not significance effect of Question12 on intranet adaptation at the $\mathrm{p}<.05$ level for conditions $[\mathrm{F}=0.020, \mathrm{p}<.8884]$, there was a significance effect of Question13 on intranet adaptation at the $\mathrm{p}<.05$ level for conditions $[\mathrm{F}=3.072$, $\mathrm{p}<.0103$ ] and finally there was a not significance effect of Question14 on intranet adaptation at the $\mathrm{p}<.05$ level for conditions $[\mathrm{F}=0.768, \mathrm{p}<.3966]$. The interaction effect between Question10, Question11, Question12, Question13 and Question14 under organizational routine factor was significant $\mathrm{F}=2.855, \mathrm{p}<01149$. In the results we claimed that organizational routine has negative effect on intranet adaptation with determining TukeyHSD Posthoc analysis. According to these results, $\mathrm{H} 0$ hypothesis is supported.

\section{Personnel Restrictions}

A two-way analysis of variance was conducted on the influence of four independent variables (Question15, Question16 and Question17) on the e-service adaptation. All effects were statistically significant at the .05 significance level (Table 5).

There was a significance effect of Question15 on eservice adaptation at the $\mathrm{p}<.05$ level for conditions $[\mathrm{F}=2.492, \mathrm{p}<.0234]$, there was a significance effect of Question16 on e-service adaptation at the $\mathrm{p}<.05$ level for conditions $[\mathrm{F}=0.151, \mathrm{p}<.066]$, there was a not significance effect of Question17 on e-service adaptation at the $\mathrm{p}<.05$ level for conditions $[\mathrm{F}=0.818, \mathrm{p}<.359]$. The interaction effect between Question15, Question16, Question17 under personnel restrictions factor was not significant $\mathrm{F}=1.702, \mathrm{p}<0.2049$. In the results we claimed that personnel restrictions have negative effect on eservice adaptation with determining TukeyHSD Posthoc analysis.

A two-way analysis of variance was conducted on the influence of four independent variables (Question15, Question16 and Question17) on the intranet adaptation. All effects were statistically significant at the .05 significance level.

There was a significance effect of Question15 on intranet adaptation at the $\mathrm{p}<.05$ level for conditions $[\mathrm{F}=10.034, \mathrm{p}<.0043]$, there was a significance effect of Question16 on intranet adaptation at the $\mathrm{p}<.05$ level for conditions $[\mathrm{F}=6.249, \mathrm{p}<.020]$, there was a not significance effect of Question 17 on intranet adaptation at the $\mathrm{p}<.05$ level for conditions $[\mathrm{F}=0.140, \mathrm{p}<.7119]$. The interaction effect between Question15, Question16, Question17 under personnel restrictions factor was significant $F=3.011, \mathrm{p}<0.096$. In the results we claimed that personnel restrictions have negative effect on intranet adaptation with determining TukeyHSD Posthoc analysis. Ho hypothesis is supported.

\section{Risk Taking}

A two-way analysis of variance was conducted on the influence of four independent variables (Question24, Question25 and Question26) on the e-service adaptation. All effects were statistically significant at the .05 significance level (Table 6).

There was a significance effect of Question24 on eservice adaptation at the $\mathrm{p}<.05$ level for conditions $[\mathrm{F}=3.389, \mathrm{p}<.05445]$, there was a significance effect of Question25 on e-service adaptation at the $\mathrm{p}<.05$ level for conditions $[\mathrm{F}=4.914, \mathrm{p}<.03580]$ and finally there was a significance effect of Question26 on e-service adaptation at the $\mathrm{p}<.05$ level for conditions $[\mathrm{F}=4.895, \mathrm{p}<.0193]$. The interaction effect between Question24, Question25 and Question26 under risk-taking factor was significant $\mathrm{F}=5.991, \mathrm{p}<0.0332$. In the results risk-taking has positive effect on e-service adaptation with determining TukeyHSD Posthoc analysis. 
A two-way analysis of variance was conducted on the influence of four independent variables (Question24, Question25 and Question26) on the intranet adaptation. All effects were statistically significant at the .05 significance level.

There was a significance effect of Question24 on intranet adaptation at the $\mathrm{p}<.05$ level for conditions $[\mathrm{F}=6.716, \mathrm{p}<.023]$, there was a significance effect of Question25 on intranet adaptation at the $\mathrm{p}<.05$ level for conditions $[\mathrm{F}=14.318, \mathrm{p}<.002]$ and finally there was a significance effect of Question26 on intranet adaptation at the $\mathrm{p}<.05$ level for conditions $[\mathrm{F}=4.648, \mathrm{p}<.052]$. The interaction effect between Question24, Question25, Question26 under risk-taking factor was significant $\mathrm{F}=22.813, \mathrm{p}<0.001$. In the results risk-taking has positive effect on intranet adaptation with determining TukeyHSD Posthoc analysis. According to these results, $\mathrm{H} 0$ hypothesis is supported.

Table 3. Machine Bureaucracy

\begin{tabular}{|l|l|l|l|l|l|l|l|}
\hline Machine Bureaucracy & $\begin{array}{l}\text { Mean } \\
\text { Square }\end{array}$ & $\begin{array}{l}\mathrm{F} \\
\text { value }\end{array}$ & $\mathrm{p}$ & Hypotheses & $\begin{array}{l}\text { Mean } \\
\text { Square }\end{array}$ & $\begin{array}{l}\mathrm{F} \\
\text { value }\end{array}$ & $\begin{array}{l}\mathrm{p} \\
\text { Hypotheses }\end{array}$ \\
\hline Question5-E-service Adaptation & 0.227 & 0.114 & 0.7383 & Question7-E-service Adaptation & 2.573 & 1.293 & 0.2671 \\
\hline Question5-Intranet Adaptation & 1.0059 & 0.883 & 0.357 & Question7-Intranet Adaptation & 0.9820 & 2.862 & 0.0363 \\
\hline Question6-E-service Adaptation & 7.289 & 3.665 & 0.0481 & Question8-E-service Adaptation & 0.339 & 2.170 & 0.0683 \\
\hline Question6-Intranet Adaptation & 2.2989 & 2.018 & 0.0169 & Question8-Intranet Adaptation & 0.2476 & 0.217 & 0.645 \\
\hline $\begin{array}{l}\text { H1a Machine Bureaucracy-Intranet } \\
\text { Adaptation }\end{array}$ & 0.4239 & 2.372 & 0.0548 & $\begin{array}{l}\text { H1b Machine Bureaucracy - E- } \\
\text { service Adaptation }\end{array}$ & 4.863 & 2.445 & 0.1316 \\
\hline
\end{tabular}

Table 4. Organizational Routine

\begin{tabular}{|l|l|l|l|l|l|l|l|}
\hline Organizational Routine & $\begin{array}{l}\text { Mean } \\
\text { Square }\end{array}$ & $\begin{array}{l}\mathrm{F} \\
\text { value }\end{array}$ & $\mathrm{p}$ & Hypotheses & $\begin{array}{l}\text { Mean } \\
\text { Square }\end{array}$ & $\begin{array}{l}\mathrm{F} \\
\text { value }\end{array}$ & $\mathrm{p}$ \\
\hline Hypotheses & 4.549 & 2.906 & 0.0190 & Question12-E-service Adaptation & 2.513 & 3.053 & 0.0323 \\
\hline Question10-E-service Adaptation & 0.001 & 0.001 & 0.9803 & Question12-Intranet Adaptation & 0.023 & 0.020 & 0.884 \\
\hline Question10-Intranet Adaptation & 4.273 & 1.790 & 0.2038 & Question13-E-service Adaptation & 4.576 & 1.917 & 0.1895 \\
\hline Question11-E-service Adaptation & 0.014 & 3.013 & 0.0512 & Question13-Intranet Adaptation & 3.468 & 3.072 & 0.0103 \\
\hline Question11-Intranet Adaptation & 4.341 & 1.819 & 0.2005 & & & & \\
\hline Question14-E-service Adaptation & 0.867 & 0.768 & 0.3966 & & & & \\
\hline Question14-Intranet Adaptation & 3.224 & 2.855 & 0.1149 & $\begin{array}{l}\text { H1b Organizational Routine - E- } \\
\text { service Adaptation }\end{array}$ & 0.121 & 0.051 & 0.8253 \\
\hline $\begin{array}{l}\text { H1a Organizational Routine - } \\
\text { Intranet Adaptation }\end{array}$ & & & & & \\
\hline
\end{tabular}

Table 5. Personnel Restrictions

\begin{tabular}{|c|c|c|c|c|c|c|c|}
\hline \multicolumn{8}{|l|}{ Personnel Restrictions } \\
\hline Hypotheses & $\begin{array}{l}\text { Mean } \\
\text { Square }\end{array}$ & $\begin{array}{l}\mathrm{F} \\
\text { value }\end{array}$ & $\mathrm{p}$ & Hypotheses & $\begin{array}{l}\text { Mean } \\
\text { Square }\end{array}$ & $\begin{array}{l}\mathrm{F} \\
\text { value }\end{array}$ & $\mathrm{p}$ \\
\hline Question15-E-service Adaptation & 3.404 & 2.492 & 0.0234 & Question17-E-service Adaptation & 0.818 & 0.359 & 0.5552 \\
\hline Question15-Intranet Adaptation & 7.375 & 10.034 & 0.00430 & Question17-Intranet Adaptation & 0.103 & 0.140 & 0.7119 \\
\hline Question16-E-service Adaptation & 0.151 & 0.066 & 0.7991 & & & & \\
\hline Question16-Intranet Adaptation & 4.593 & 6.249 & 0.0200 & & & & \\
\hline $\begin{array}{l}\text { H1a Personnel Restrictions-Intranet } \\
\text { Adaptation }\end{array}$ & 2.213 & 3.011 & 0.096 & $\begin{array}{l}\text { H1b Personnel Restrictions- E- } \\
\text { service Adaptation }\end{array}$ & 3.885 & 1.702 & 0.2049 \\
\hline
\end{tabular}

Table 6. Risk Taking

\begin{tabular}{|c|c|c|c|c|c|c|c|}
\hline \multicolumn{8}{|l|}{ Risk Taking } \\
\hline Hypotheses & $\begin{array}{l}\text { Mean } \\
\text { Square }\end{array}$ & $\begin{array}{l}\mathrm{F} \\
\text { value }\end{array}$ & $\mathrm{p}$ & Hypotheses & $\begin{array}{l}\text { Mean } \\
\text { Square }\end{array}$ & $\begin{array}{l}\mathrm{F} \\
\text { value }\end{array}$ & $\mathrm{p}$ \\
\hline Question24-E-service Adaptation & 4.573 & 3.389 & 0.0544 & Question26-E-service Adaptation & 2.791 & 4.895 & 0.019 \\
\hline Question24-Intranet Adaptation & 1.026 & 6.716 & 0.023 & Question26-Intranet Adaptation & 0.710 & 4.648 & 0.05 \\
\hline Question25-E-service Adaptation & 4.345 & 4.914 & 0.0358 & & & & \\
\hline Question25-Intranet Adaptation & 2.187 & 14.318 & 0.002 & & & & \\
\hline $\begin{array}{l}\text { H1a Risk Taking-Intranet } \\
\text { Adaptation }\end{array}$ & 3.485 & 22.813 & 0.001 & $\begin{array}{l}\text { H1b Risk Taking- E-service } \\
\text { Adaptation }\end{array}$ & 5.458 & 5.991 & 0.0339 \\
\hline
\end{tabular}

\section{CONCLUSION}

Within the scope of the study, the factors affecting the use of IT in decision-making processes in municipalities were examined. The survey was applied to 61 branch managers in the metropolitan municipality. Reliability and validity analyzes of the questionnaire were conducted.

The answers to the first factor, the questions under the machine bureaucracy, indicate that the organization is 
governed by a complete machine bureaucracy. In this context, when the answers of the questions are examined, it is seen that there is a solid hierarchy within the institution during the decision-making process. This structure has a negative effect on the innovative features of the managers. If we take this into consideration, our first hypothesis proves that the machine bureaucracy affects e-services and intranet adaptation negatively in institutional decision-making processes.

When the organizational routine factor, the second factor, is examined; it is seen that the employees of the institution usually deal with certain tasks during the day. Although employees are willing to produce innovative ideas, creativity is hidden because of the mechanics and obstacles of the managers. The use of information technology at the management level will make daily business processes more efficient at a high level. In addition, if a municipal integrated information technology based system is installed, managers are expected to adapt quickly. All these conclusions are in light; it has been found that e-services and intranet adaptation are negatively affected in the organizational routine decisionmaking phase.

The factor of personnel constraints was examined with 5 questions. First of all, there is no reward system to support innovation in the municipality. Managers' innovative ideas are not as high as senior executives. This result shows that there is a solid staff structure in the municipality. This structure; it has been found that the use of information technology in decision making affects positively the contrary to the hypothesis.

The last factor measures the risk taking tendencies. In this context, when the answers given by managers to take risks in the use of information technology are examined, it turns out that a large part is not afraid of taking risks. On the other hand, the institution was found not to have a dynamic entrepreneur in terms of innovation. In addition to not being a dynamic institution, it has emerged that information technologies are encouraged to be established. Indeed, these two opposing trends suggest that the institution wants to do an innovative job, but not in its overall structure. When the answers to all these questions are examined, it is revealed that the managers of the institution are not afraid to take risks and affirmation of e-services and intranet adaptation positively in the decision making stage.

\section{REFERENCES}

[1] S. Çetin, "Yerel yönetimlerde stratejik yönetim," Türk İdare Dergisi, 449, pp.93-100, 2005.

[2] S. Gülseçen, Bilgi Yönetimi Bilgi Türeticileri, Büyük Veri İnovasyon ve Kurumsal Zeka. Üniversite Yayıncılı̆̆ı. 2015.

[3] Ö. Uygun, "Belediyelerde Yönetim Bilişim Sistemleri," SAU Fen Bilimleri Enstitüsü Dergisi, 6(1), pp.119-128, 2002.

[4] F. Wahid, "Explaining failure of e-governmen implementation in developing countries: a phenomenological perspective," Seminar Nasional Aplikasi Teknologi Informasi, pp.D21-D25. 17-18 June 2011.
[5] A. Ho and A. Ni, "Explaining the adoption of egovernment features: a case study of Iowa county treasurer's offices," American Review of Public Administration, 34(2), pp.164-180, 2004.

[6] D. West, "E-government and the transformation of service delivery and citizen attitudes," Public Administration Review, 64(1), pp.15-27. 2004.

[7] M. J. Moon, "The evolution of e-government among municipalities: rhetoric or reality?", Public Administration Review, 62, pp.424 433, 2002.

[8] D. Gant, J. Gant and C.C. Johnson, State Web Portals: Delivering and Financing e-Service. Washington, DC: IBM Center for the Business of Government. 2002. From: http://businessofgovernment.org/sites/default/files/StateW ebPortals.pdf

[9] S.R. Furlong and C. M. Kerwin, "Interest group participation in rule making: A decade of change," Journal of Public Administration Research and Theory, 15, pp.353-370, 2005.

[10] J. S. Nye, "Information technology and democratic governance". In Governance.com: Democracy in the information age, E. C. Kamarck and J. S. Nye, Eds. Washington, DC: Brookings Institution Press, 2002, pp. 1-16.

[11] J. E. Fountain, Building the Virtual State: Information Technology and Institutional Change, DC: Brookings Institution. Washington, 2001.

[12] C. J. Tolbert and K. Mossberger, "The effects of egovernment on trust and confidence in government," Public Administration Review, 66, pp.354-369, 2006.

[13] E. W. Welch, C. C. Hinnant and M. J. Moon, "Linking citizen satisfaction with e-government and trust in government," Journal of Public Administration Research and Theory, 15, pp.371-391, 2005.

[14] T. La Porte, C. C. Demchak and M. De Jong, "Democracy and bureaucracy in the age of the web: empirical findings and theoretical speculations," Administration \& Society, 34, pp.411-446, 2002.

[15] S. Wang and M. Feeney, "Determinants of information and communication technology adoption in municipalities," The American Review of Public Administration. 46(3), pp.292-313, 2014.

[16] M. Ahn, "Adoption of e-communication applications in u.s. municipalities: the role of political environment, bureaucratic structure, and the nature of applications," The American Review of Public Administration, 41,(4), pp. 428-452, 2010.

[17] H. Mintzberg, The structuring of organizations. Springer, 1979.

[18] N. Hawkins, D. Wright and S. Capewell, "Heart failure services in the united kingdom: rethinking the machine bureaucracy," International Journal of Cardiology, 162(3), pp.143-148, 2013.

[19] D. Osborne and T. Gaebler, Reinventing Government. Addison-Wesley Publ.Co., 1992.

[20] R. L. Daft, "Bureaucratic versus non-bureaucratic structure and the process of innovation and change,". in Perspectives in Organizational Sociology: Theory and Research S. B. Bacharach (Ed.), 1982, pp.129-166.

[21] F. Damanpour, "Bureaucracy and innovation revisited: Effects of contingency factors, industrial sectors, and innovation characteristics," The Journal of High Technology Management Research, 7, pp.149-173, 1996.

[22] K. Laudon and J. Laudon, Management Information Systems: Managing the Digital Firm, Genişletilmiş 11. Bask1, Nobel Yayınevi, İstanbul, 2011. 
[23] M. Becker, N. Lazaric, R. Nelson and S. Winter, "Applying organizational routines in understanding organizational change," Industrial and Corporate Change, 14(5), pp.775-791, 2005.

[24] B. Bozeman and G. Kingsley, "Risk culture in public and private organizations," Public Administration Review, 58, pp.109-118. 1998.

[25] J. Hage and M. Aiken, "Routine technology, social structure, and organization goals," Administrative Science Quarterly, 14, pp.366-376, 1969.

[26] M. S. Feldman, "Organizational routines as a source of continuous change," Organization Science, 11, pp.611$629,2000$.

[27] M. Li and M. Feeney, "Adoption of electronic technologies in local u.s. governments," The American Review of Public Administration. 44(1), pp.75-91, 2012.

[28] S. K. Pandey, D. Coursey and D. P. Moynihan, "Organizational effectiveness and bureaucratic red tape: a multimethod study," Public Performance and Management Review, 30, pp.398-425, 2007.

[29] B. Bozeman and H. G. Rainey, "Organizational rules and the bureaucratic personality," American Journal of Political Science, 42, pp.163-189, 1998.

[30] R. D. Dewar and J. Dutton, "The adoption of radical and incremental innovations: an empirical analysis," Management Science, 32, pp.1422-1433, 1986.

[31] Ş. Büyüköztürk, Veri Analizi El Kitabl, 6. Baskı, Pegem A Yayıncılık, Ankara, 2006.

[32] A. Seçkin and M. Başbay, "Beden eğitimi ve spor öğretmeni adaylarının öğretmenlik mesleğine ilişkin özyeterlik inançlarının incelenmesi," Electronic Turkish Studies, 8(8), pp.253-270, 2013.

[33] J. C. Nunnally, Psychometric Theory, (2nd ed.). New York, NY: McGraw-Hill, 1978.

[34] D. S. Halaç, H. Eren and Ç. Bulut, "Sosyal Yenilikçilik: Bir Ölçek Geliştirme Çalışması," Hacettepe Üniversitesi İktisadi ve İdari Bilimler Fakültesi Dergisi, 32(1), pp.165190, 2014.

[35] S. S. Shapiro and R. S. Francia, "An approximate analysis of variance test for normality," Journal of the American Statistical Association, 67, pp.215-216, 1972.

[36] D. Norris and M. Moon, "Advancing e-government at the grassroots: tortoise or hare?", Public Administration Review, 65(1), pp.64-75, 2005.

[37] A. T.-K. Ho, "Reinventing local governments and the egovernment initiative," Public Administration Review, 62, pp.434-444, 2002.

\section{Authors' Profiles}

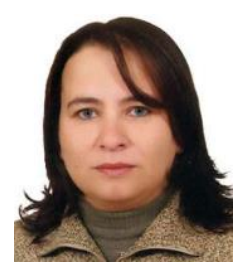

Cigdem Tarhan, is an Assoc.Prof.Dr. in Department of Management Information Systems at the Faculty of Economics and Administrative Sciences in Dokuz Eylül University, Izmir, Turkey. Her research interests are management information systems, decision support systems and geographical information systems.

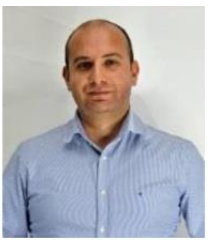

Can Aydın, is an Assistant Professor in Department of Management Information System at the Faculty of Economics and Administrative Sciences in Dokuz Eylül University, Izmir, Turkey. His research interests include business analytics, industry 4.0 and web application development and spatial data analytics.

How to cite this paper: Cigdem Tarhan, Can Aydın, "Why Should Municipalities Use Management Information Systems in Their Decision-Making Processes?", International Journal of Information Technology and Computer Science(IJITCS), Vol.11, No.4, pp.1-8, 2019. DOI: 10.5815/ijitcs.2019.04.01 